\title{
Rhizofiltration of Heavy Metals from Eutrophic Water Using Pistia Stratiotes in a Controlled Environment
}

\author{
Mohammad Mustapha Abubakar, ${ }^{2}$ Mani M. Ahmad, ${ }^{2}$ Balarabe U. Getso \\ ${ }^{1}$ Department of Biological Sciences, Federal University Dutse, Nigeria. \\ ${ }^{2}$ Department of Biology, Kano University of Science and Technology, Wudil, Nigeria.
}

\begin{abstract}
The remediation of waters polluted with heavy metals using Pistia stratiotes was studied with the aim of assessing the potential of P.stratiotes as a rhizofiltration agent. Wild plants of P. stratiotes were grown in various high concentration solutions of Chromium $(\mathrm{Cr}), \mathrm{Lead}(\mathrm{Pb})$ and Nickel(Ni). The plants were allowed to grow for twenty one days before harvesting. Metal concentrations were then determined using Atomic Absorption Spectrophotometry. The data generated from the analysis was subjected to analysis of variance (ANOVA) to determine if there is any significant difference between the treatments and the rate of multiplication of the plants. Different concentrations of the metals that were over 300 times what is obtainable in normal plants were observed. The uptake of Ni by P. stratiotes is higher than the uptake of other metals in this study. The uptake of metals was greater in the 2000 ppm treatment than in the other treatments. The plant is able to tolerate the high concentration of heavy metals without showing any visible symptoms. It is also capable of growing past and reproducing within the shortest possible time. P. stratiotes is an excellent candidate for rhizofiltration of heavy metal from polluted waters.
\end{abstract}

Key Words: Heavy metals, Phytoremediation, Pistia, Potential, Rhizofiltration,

\section{Introduction}

Rhizofiltration is a technique designed for the removal of heavy metals from the aquatic environment using plants. In this process, plants were grown in polluted waters, where the plants absorb the metals and concentrate them in roots and shoots [1]. The contamination of water by heavy metals is a significant environmental problem. Plants and fishes harvested from such contaminated waters contain significant levels of the heavy metals that can impair human health. Plants that can accumulate and tolerate high concentration of heavy metals in their shoots and roots are called hyperaccumulators. These are candidates for rhizofiltration [2].

Several hyperaccumulators have been found by several workers, they include Thlaspi caerulescens [3], Sedum alfredi [4], Arabidopsis halleri [5], Brassica campestris [6]and Pistia stratiotes [7]. This technique is of advantage since it can be applied to a range of heavy metals and it can generate a recyclable metal rich plant residue with minimal environmental disturbance. The aim of this study is to assess the potential of Pistia stratiotes as a rhizofiltration agent of heavy metals in polluted waters.

\section{Methodology}

Wild P. stratiotes plants where collected from Gaya pond in Kano state. The pond is relatively undisturbed, with water having the following parameters. $\mathrm{pH} 7.71$, nitrogen 122ppm, phosphorus 93ppm, lead $15 \mathrm{ppm}$, chromium $21 \mathrm{ppm}$ and nickel $135 \mathrm{ppm}$. The collected plants where washed with distilled water to eliminate dirt, possible parasites or their eggs and finally rinsed with deionised water [8].

Solutions of heavy metals were prepared for each metal by dissolving salts of the metal in distilled water. Solutions corresponding to 1800ppm, 2000ppm and 2400ppm of chromium $(\mathrm{Cr})$, lead $(\mathrm{Pb})$ and nickel $(\mathrm{Ni})$ were prepared using potassium dichromate $\left[\mathrm{K}_{2} \mathrm{Cr}_{2} \mathrm{O}_{7}\right]$, lead nitrate $\left[\mathrm{Pb}\left(\mathrm{NO}_{3}\right)_{2}\right]$ and nickel sulphate $\left[\mathrm{NiSO}_{4} \cdot 6 \mathrm{H}_{2} \mathrm{O}\right]$ respectively.

Five plants each were cultured in rectangular plastic aquarium, measuring one meter by half a meter. The solutions were made up to mark by distilled water regularly and were allowed to stay for twenty one days. During which small doses of NPK fertilizer were added for the rapid growth of the plants. The aquaria were kept in semi-shaded area to prevent bleaching of tender leaves. Another aquarium with distilled water only was used as a control. The plants were harvested separately according to treatment. The complete plant (root, stem and leaf) was oven dried at $90^{\circ} \mathrm{C}$ for 48 hours. $1 \mathrm{~g}$ of dry matter was weighed into $50 \mathrm{ml}$ beakers as described by [8]. $10 \mathrm{ml}$ mixture of analytical grade acids: $\mathrm{HNO}_{3}: \mathrm{H}_{2} \mathrm{SO}_{4}: \mathrm{HClO}_{4}$ in the ratio $1: 1: 1$ was then added to the beakers. The beakers containing the samples were covered with watch glasses and left overnight. The digestion was carried out at a temperature of $90^{\circ} \mathrm{C}$ until $4 \mathrm{ml}$ of the mixture was left in the beaker. Then, a further $10 \mathrm{ml}$ of the mixture of acids was added. This mixture was allowed to evaporate to a volume of about $4 \mathrm{ml}$. after cooling; the solution was filtered to remove small quantities of waxy solids and made up to a final volume of $50 \mathrm{ml}$ with distilled water. Metal concentrations were then determined using Atomic Absorption Spectrophotometer. 
The data generated from the analysis was subjected to analysis of variance (ANOVA) to determine if there is any significant difference between the treatments and the rate of multiplication of the plants.

\section{Results And Discussion}

Results obtained from the study indicated the concentration of heavy metals in the plants ranging from $121.96 \mu \mathrm{g} / \mathrm{g}$ to $304.52 \mu \mathrm{g} / \mathrm{g}$ for $\mathrm{Cr}, 182.12 \mu \mathrm{g} / \mathrm{g}$ to $419.43 \mu \mathrm{g} / \mathrm{g}$ for Pb and $261.81 \mu \mathrm{g} / \mathrm{g}$ to $446.33 \mu \mathrm{g} / \mathrm{g}$ for Ni all in the $1800 \mathrm{ppm}$ treatment. In the 2000ppm treatment the lowest concentration observed was in the $\mathrm{Cr}$ metal treatment with $106.98 \mu \mathrm{g} / \mathrm{g}$, and the highest concentration was recorded in Ni treatment with $520.12 \mu \mathrm{g} / \mathrm{g}$. The $2400 \mathrm{ppm}$ treatment recorded a range of $93.96 \mu \mathrm{g} / \mathrm{g}$ in $\mathrm{Cr}$ which is the lowest concentration observed and 466.98 $\mu \mathrm{g} / \mathrm{g}$ in Ni. The uptake of Ni by P. stratiotes is higher than the uptake of other metals in this study. The most persuasive ecological explanation for the hyperaccumulation of $\mathrm{Ni}$ according to [9] appears to be the defensive role against herbivores or pathogens. The normal range of $\mathrm{Ni}$ in the environment is 2 to $100 \mathrm{ppm} \mathrm{[10].}$

The plants in the control treatment generally recorded very low metal concentrations, with the lowest being $1.34 \mu \mathrm{g} / \mathrm{g}$ in $\mathrm{Cr}$ and the highest being $7.11 \mu \mathrm{g} / \mathrm{g}$ in $\mathrm{Pb}$. Mean concentrations of metals in plants per treatment is presented in table 1 .

Table 1. Mean heavy metal levels in P. stratiotes plants in $\mu \mathrm{g} / \mathrm{g}$.

\begin{tabular}{llll}
\hline Treament & Pb & $\mathbf{C r}$ & $\mathbf{N i}$ \\
\hline $1800 \mathrm{ppm}$ & $372.12 \pm 1.02$ & $272.02 \pm 1.76$ & $380.86 \pm 1.02$ \\
$2000 \mathrm{ppm}$ & $381.61 \pm 2.71$ & $332.98 \pm 2.11$ & $470.26 \pm 1.61$ \\
$2400 \mathrm{ppm}$ & $379.10 \pm 1.98$ & $298.61 \pm 1.90$ & $386.31 \pm 2.11$ \\
Control & $6.34 \pm 1.31$ & $4.04 \pm 1.21$ & $3.11 \pm 1.33$ \\
\hline
\end{tabular}

The concentration of metals in the plants is more than 300 times that in the water. The uptake of metals was greater in the $2000 \mathrm{ppm}$ treatment than in the other treatments. There was increasing uptake of heavy metals with increased concentration of metals in water; however the uptake of the metals did not increase significantly after a certain level. This result agrees with the findings of [11] who observed that the increase of external concentration of metals from 5 to $7.5 \mu \mathrm{M}$ significantly increased metal concentration in plants of sunflower in a hydrophonic culture. But a higher external metal concentration $(10 \mu \mathrm{M})$ did not cause a further increase of plant metal accumulation.

Results of the analysis of variance (ANOVA) showed that there was significant difference between the treatments (table 2).

Table 2. ANOVA for heavy metal treatments

\begin{tabular}{|c|c|c|c|c|c|}
\hline Source & DF & SS & MS & Fcal & Ftab 10.05 \\
\hline Plant growth & 3 & $11,441.08$ & 5720.55 & $26.16^{* *}$ & \\
\hline
\end{tabular}

*** Highly significant difference

The growth and multiplication of the plants is greater in the control treatment than in the other treatments. The control plants show highest increase in biomass during the study period. The plants in this treatment showed greatest rate of multiplication of plants in the study period. This is because some heavy metals especially $\mathrm{Pb}$ had the tendency of retarding plant growth. This is shown by [12] who reported that fresh mass of cowpea (Vigna unguiculata) was reduced by $10 \%$ at $0.06 \mu \mathrm{M}$ of $\mathrm{Pb}$. [13] also reported considerably reduced dry weight in Basella rubra exposed to $\mathrm{Pb}$. The fast growth and rapid reproduction of $\mathrm{P}$. stratiotes makes the plant a very good candidate for phytoremediation. At present, there are about 400 known hyperaccumulator plants [14]. The best among them for the purpose of phytoremediation are those that can hyperaccumulate metals, tolerate such metals and produce high biomass within a short time. P. stratiotes is fast growing and can grow in several climatic conditions. This collaborates with the findings of [7]. 


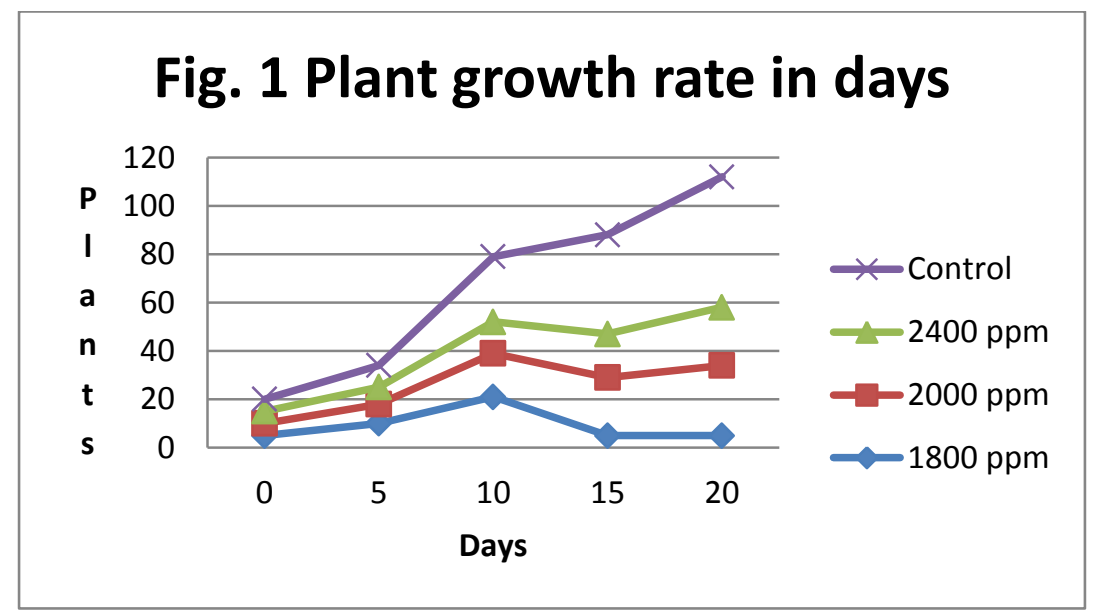

\section{Conclusion}

The results of the study showed that P. stratiotes accumulates metals more than 300 times the concentration accumulated by conventional plants. The plant is able to tolerate the high concentration of heavy metals without showing any visible symptoms. P. stratiotes is capable of growing past and reproducing within the shortest possible time. This is evident in the plant multiplying from five plants to over 110 plants in just twenty one days. The plant is capable of accumulating various metals. The greater uptake of $\mathrm{Ni}$ by the plant is a survival mechanism against grazing and pathogens. Therefore P. stratiotes is an excellent candidate for rhizofiltration of heavy metal from polluted waters.

\section{References}

[1]. Zhu, Y. Z. Pilon-Smits, E. A. H; Tarun, A. S; Weber, S. U, Jouanin, L; and Terry, N. Cadmium Tolerence and accumulation in Indian Mustard, is Enhanced by overexpressing g - Glutamylcysteine synthetase. Plant physiol; 212, 1999, 1169 - 1177

[2]. Blaylock, M. J and Huang, J. W. Phytoextraction of metals. In phytoremediation of Toxic metals: using plants to clean up the Environment; Raskin, I. and Ensley. B. D. (Eds) John Wiley \& Sons: New York. 2000, 53 - 70

[3]. Pence, N, S; Larsen, P. B; Ebbs, S. D.; Letham, D. L. D; Lasat, M. M; Garvin, D. F., Eide, D; and Kochian, L. V. The molecular physiology of heavy metal transport in the $\mathrm{Zn} / \mathrm{Cd}$ hyperaccumuletor Thlaspi caerulescens. Proceedings of the National Academy of Science 97 2000, $4956-4960$

[4]. Yang, X. E; Long, X. X; Ye, H. B; He, Z. L, Calvert, D. U. and Stoffelli, P. J. Cadmum tolerance and hyperaccumulation in a new $\mathrm{Zn}$ - hyperaccumulating plants species (sedum alfredii Hance). Plant and soil, $2592004,181-189$.

[5]. Bert, V; Meerts P., Saumitou - Laprade, P., Salis, P., Gruber, W; and Verbruygen, N. Genetic basis of Cd tolerance and hyperaccumulation in Arabidopsis halleri; Plant and soil 249, 2003, 9 - 18

[6]. Glick, B. R. Phytoremediation synergistic use of plants and bacteria to clean up the environment. Biotechnology Advances, 21, 2003, $383-393$

[7]. Moodley, K. G., Baijnath, H., Southway-Ajulu, F. A., Maharaj, S. and Chetty, S.R. Determination of Cr, Pb, Ni in water sludge and plants from settling ponds of a sewage treatment works. Water SA, 33, 2007, 723 - 728.

[8]. Yusuf A.A; Arowolo, T. and Bamgbose O. $\mathrm{Cd}, \mathrm{Cu}$ and Ni levels in vegetables from industrial and residential Areas of Lagos city Nigeria. Global journal of Environmental Sciences vol. 1, 2002, 1-3.

[9]. Martens, S. N. and Boyd, R.S. The defensive role of Ni hyperaccumulation by plants. A field Experiment. American Journal of Botany, 89, 2002, $998-1003$

[10]. Gardea-Torresday, J. L., Peralta-Videa, J.R., De La Rosa, G. and Parsons, J. G. Phytoremediation of heavy metals and study of the metal coordination by x-ray absorption spectroscopy. Coordination Chemistry Review, 249, 2005, $1797-1810$

[11]. Nehnevajova, E. Non GMO approach for the improvement of heavy metal accumulation and extraction of high yielding crop species for efficient phytoextraction of contaminated soil. Ph. D. thesis. School of Architecture, civil and environmental engineering. Swiss federal institute of technology Lausanne (EPFL), 2005

[12]. Kopittke, P. M., Asher, C. J., Kopittke, R. A. and Menzies, N. W. Toxic effects of $\mathrm{Pb}^{2+}$ on growth of cowpea (Vigna unguiculata). Environmental Pollution 150, 2007, 280-287

[13]. Kibria, M.G., Osman, K. T., Islam, M. and Ahammad, M. J. Effect of applied lead on the growth and accumulation of lead in Indian Spinach in three textural groups of soils. The Chittagong Univ. J. B. Sci., vol. 5 (1\&2, ) 2010, 113 -124.

[14]. Salt, D. E. and Kramer, U. Mechanisms of metal hyperaccumulation in plants. In Raskin I. and Ensley, B. D. (Eds). Phytoremediation of toxic metals: using plants to clean-up the environment. New York, John Wiley and Sons, Inc, 2000. 